\title{
SMART TOURISM: AKSENTUASI KESIAPAN HOMESTAY DI KAWASAN EKONOMI KHUSUS TANJUNG LESUNG, PANDEGLANG - BANTEN
}

\author{
Nurdin Hidayah ${ }^{1}$ dan Herlan Suherlan ${ }^{2}$ \\ ${ }^{1,2}$ Sekolah Tinggi Pariwisata Bandung, Indonesia, email: nurdin@stp-bandung.ac.id
}

\begin{abstract}
\begin{tabular}{|c|}
\hline \hline \\
\hline \\
Histori Artikel \\
Submitted: \\
01 Februari 2020 \\
Reviewed: \\
24 Februari 2020 \\
Accepted: \\
05 Maret 2020 \\
Published: \\
15 Mei 2020 \\
\hline
\end{tabular}
\section{ABSTRAK}

Penelitian ini bermaksud untuk memperoleh informasi mengenai gambaran yang komprehensif mengenai kesiapan sarana Homestay dalam kerangka pengembangan Smart Tourism di Kawasan Tanjung Lesung Pandeglang Banten. Penelitian ini menggunakan disain penelitian kualitatif dengan pendekatan fenomenografi. Pengumpulan data dilakukan dengan wawancara ke para pemagku kepentingan yang terlibat, observasi ke homestay-homestay yang ada di sekitar wilayah penelitian, serta studi terhadap dokumen-dokumen yang terkait dengan program homestay dan digitalisasi pariwisata, baik ditingkat pusat, regional maupun lokal. Hasil penelitian menunjukam bahwa: (1) dasar utama program homestay dalam kerangka smart tourism di Tanjung Lesung adalah untuk menggerakan ekonomi dan kesejahteraan masyarakat setempat; (2) Implementasi pengembangan sarana homestay dalam kerangka smart tourism di Tanjung Lesung dilakukan secara bertahap, melalui skema pembangunan homestay dengan pendekatan konversi, renovasi, revitalisasi, dan pembangunan baru; (3) Penerapan smart tourism di Tanjung Lesung dilakukan melalui penggunaan teknologi informasi melalui program pemasaran digital seperti online market place; internet marketing; Pokdarwis dan 10 desa wisata percontohan dalam program Indonesia Tourism Exchange (ITX).
\end{abstract}

Kata Kunci: Smart Tourism, Smart Destination, Pariwisata Digital, Tourism 4.0, Homestay

\section{SMART TOURISM: ACCENTUATION OF HOMESTAY READINESS IN TANJUNG LESUNG SPECIAL ECONOMIC ZONE, PANDEGLANG - BANTEN}

\begin{abstract}
This study intends to obtain a comprehensive information about Homestay facilities readiness within the Smart Tourism development framework in Tanjung Lesung Pandeglang, Banten. This study uses a qualitative research design with a phenomenographic approach. Data collection was carried out by interviewing existing stakeholders, observing homestays in the study area and studying documents related to the Homestay program and tourism digitizing. The results of the study show that 1) The homestay program within smart tourism framework in Tanjung Lesung is based on driving the economy and welfare of the host community; 2) Implementation of the homestay facilities development within smart tourism framework in Tanjung Lesung is carried out in four stages: conversion, renovation, revitalization, and new development; 3) The application of smart tourism in Tanjung Lesung is done with information technology through marketing programs such as online market places; Pokdarwis and 10 pilot tourism villages in the Indonesia Tourism Exchange Program (ITX).
\end{abstract}

Keywords : Smart Tourism, Smart Destination, Digital Tourism, Tourism 4.0, Homestay 


\section{PENDAHULUAN}

Pemerintah Indonesia melalui Kementerian Pariwisata telah menetapkan strategi pengembangan 10 (sepuluh) destinasi pariwisata prioritas (DPP) dalam Renstra 2015-2019. Strategi tersebut biasa disebut sebagai Ten New Bali dengan memperioritaskan akselerasi pada pembangunan 7 (tujuh) Kawasan Strategis Pariwisata Nasional (KSPN) dan 3 (tiga) Kawasan Ekonomi Khusus (KEK).Kebijakan tersebut pada dasarnya bertujuan untuk meningkatkan daya saing pariwisata Indonesia dalam index daya saing yang dikeluarkan oleh World Travel \& Tourism Council (WTTC).

Dalam meningkatkan daya saing pariwisata, pertama yang harus dilakukan adalah dengan menciptakan proposisi nilai (value proposition) yang mengedepankan kualitas pengalaman bagi pengunjung. Karena inti dari produk wisata adalah pengalaman (experiences). Menciptakan pengalaman dapat diraih dari pemahaman mengenai kebutuhan (needs), keinginan (wants) dan permintaan (demand) yang dicerminkan dalam sikap dan atau perilaku pasar (Hidayah, 2019).

Yahya (2017), menyatakan bahwa: "Kondisi pasar sudah berubah, "Hampir $63 \%$ transaksi jasa travel dilakukan secara online sehingga bila biro perjalanan tidak segera menyesuaikan diri ke digital atau tetap konvensional maka nasibnya akan seperti Wartel (Warung Telekomunikasi). Perubahan pasar ini dipengaruhi oleh gaya hidup wisatawan yang juga berubah. Wisatawan dalam melalukan perjalanan (travelling) tak lepas dari digital; mulai dari mencari dan melihat-lihat informasi (look), kemudian memesan paket wisata yang diminati (book) hingga membayar secara online (pay). Sekitar $70 \%$ wisman melakukan searchand share menggunakana media digital".

Fenomena yang lain adalah bahwa pada era milenial saat ini, permintaan pengunjung memiliki kecenderungan (trends) yang menginginkan kemudahan dan cara-cara instan. Hal tersebut salah satunya dikarenakan oleh perkembangan teknologi informasi dan komunikasi (TIK) yang semakin pesat yang telah banyak mempengaruhi seluruh tatanan kehidupan sosial masyarakat. Sehingga pada saat ini, industri pariwisata sudah mulai menunjukan ketergantungannya terhadap TIK dalam menciptakan, mengkomunikasikan dan menyampaikan nilai (value) kepada pengunjung agar lebih kompetitif. Kementerian Pariwisata telah menanggapi isu penggunaan TIK dalam industri pariwisata ini, salah satunya dengan menerapkan digital tourism sebagai strategi prioritas. Aplikasi dari strategi ini salah satunya adalah dengan mencanangkan Tourism 4.0 yang dimulai dengan mengembangkan suatu platform destination marketplace yang diberi nama ITX (Indonesia Tourism Exchange).

Selain digital tourism, Yahya(2017), menegaskan bahwa kementerian pariwisata juga tengah menggenjot program homestay untuk mendukung sarana amenitas. Kementerian Pariwisata akan menggiring Indonesia menjadi negara dengan homestay terbesar, terbanyak, dan terbaik dunia. Target jumlah homestay baru pada 2019 adalah 100.000 yang akan tersebar di seluruh Indonesia, minimal di 10 Bali Baru, atau 10 Destinasi Prioritas yang sudah ditetapkan sebelumnya. Tahun ini 2017, ditargetkan 20.000, tahun 2018 ditambah 30.000, dan 2019 dibangun 50.000 yang bakal mencapai 100.000 pada 2019. Homestay itu dikelola secara korporasi, bukan cara koperasi. Homestay ini dijalankan dengan mesin baru, model bisnis baru, berbasis pada digital. Beliau juga menegaskan bahwa, program homestay desa wisata yang dilaksanakan mulai tahun ini merupakan kontribusi Kemenpar terhadap Program Sejuta Rumah bagi Masyarakat Berpenghasilan Rendah (MBR). Pembangunan homestay mempunyai nilai strategis. Terutama untuk memperkuat unsur Amenitas dalam teori 3A, yakni atraksi, amenitas, dan aksesibilitas.

Penggunaan TIK (seperti: internet of things, cloud computing, big data dan digital 
tourism) dengan tujuan untuk memberikan kemudahan dan pelayanan instan serta real time kepada pengunjung, pada industri pariwisata dikenal dengan istilah smart tourism. Menurut Buhalis dan Amaranggana (2014), konsep smart tourism dapat dilakukan dengan menggunakan TIK di mana-mana pada semua organisasi dan entitas yang ada di destinasi pariwisata untuk meningkatkan kualitas pengalaman pengunjung. Dari hal tersebut dapat diartikan bahwa, pengaplikasian smart tourism di destinasi pariwisata pada saat ini sudah menjadi keniscayaan dalam usaha meningkatkan daya saing destinasi pariwisata.

Dalam pengembangan 10 destinasi pariwisata prioritas, KEK dibangun dengan tujuan untuk memudahkan seluruh pihak yang berkepentingan dalam melakukan kegiatannya, baik dari sisi supply maupun dari sisi demand. Untuk itu, konsep KEK yang didukung oleh penggunaan TIK akan menjadi destinasi pariwisata yang menerapkan konsep smart tourism.KEK Tanjung Lesung (KEK TL) merupakan salah satu dari tiga KEK yang dikembangkan pada saat ini. Dari sisi demand, karakteristik pengunjung KEK TL menurut Anindita dkk. (2017) sangat sesuai dengan kecenderungan pasar saat ini yaitu jenis wisatawan yang melakukan perjalanan instan yang membutuhkan koneksi internet dan aplikasi yang dapat mempermudah mereka saat traveling. Sedangkan dari sisi supply, produk diarahkan untuk mengoptimalkan kesejahteraan masyarakat setempat, dengan mengembangkan desa wisata yang identik dengan homestay.

Untuk itu, agar KEK TL memiliki daya saing yang mumpuni, maka diperlukan penerapan strategi yang smart, sehingga sama halnya dengan perumusan strategi lainnya, strategi yang smart memerlukan informasi mengenai peluang dan kesiapan dari sumber dayanya itu sendiri. Jika dari sisi peluang (market attracetivenes), karakteristik pasar KEK TL sangat sesuai dengan penggunaan konsep smart tourism, tetapi dari sisi kesiapan sumberdaya, khususnya homestay masih belum diketahui dengan jelas.

Atas dasar fenomena tersebut, maka diperlukan penelitian mengenai kesiapan sarana homestay di KEK TL-Pandeglang dalam kerangka pengembangan Smart Tourism dengan pertanyaan penelitian sebagai berikut: (1) Bagaimana program homestay desa wisata dalam kerangka konsep smart tourism di Tanjung Lesung Kabupaten Pandeglang Banten? (2) Bagaimana implementasi program homestay yang berbasis desa wisata dalam kerangka konsep smart tourism di Tanjung Lesung Kabupaten Pandeglang Banten? (3) Bagaimana pemahaman para pemangku kepentingan dalam menerapkan smart tourism di Tanjung Lesung Kabupaten Pandeglang Banten?

\section{LITERATUR REVIEW}

\section{Smart Tourism}

Menurut Wang, Jin \& Zhou (2012), kata "smart" mempunyai arti "bijaksana" (wisdom). Secara eksplisit, "smart" juga dapat berarti "teroptimisasi terhadap kebutuhan-kebutuhan yang spesifik" (Gretzel, Sigal dkk., 2015). Sementara itu Harrison dkk. (2010) berpendapat bahwa sifat smart terbentuk ketika individu atau grup mengeksploitasi operasi data secara real-time, yaitu dengan menggunakan analisis yang kompleks untuk memodelkan, mengoptimisasikan, dan memvisualisasikan data yang ada sebagai dasar pembuatan keputusan yang lebih baik. Selain itu, istilah "smartness" bukan hanya selalu berkaitan dengan kemajuan teknologi, tetapi juga berkaitan erat dengan interkoneksi, sinkronisasi, dan penggunaan berbagai teknologi secara bersamaan (Höjer \& Wangel, 2015; Widjaja dkk., 2016). Kata tourism (kepariwisataan) menurut UNWTO dalam Gretzel dkk. (2015) adalah fenomena sosial, budaya dan ekonomi yang melibatkan pergerakan manusia ke negara atau tempat diluar kebiasaan di lingkungannya untuk tujuan personal atau 
tujuan bisnis.Secara khusus, Werthner, Koo, Gretzel, \& Lamfus (2015) mendefinisikan smart tourism sebagai penggunaan solusi teknologi, khususnya pengembangan aplikasi perangkat bergerak (mobile applications) di dalam konteks tahapan perjalanan (sebelum, selama, dan sesudah perjalanan) dengan mengintegrasikan data yang didapatkan dari infrastruktur fisik seperti sensor.

Lebih lanjut, smart tourism terfokus terhadap pengaturan dan penyampaian pengalaman serta jasa kepariwisataan yang pintar (intelligent) yang dihasilkan oleh stakeholders yang tergabung di dalam ekosistem smart tourism seperti: produsen, distributor, wisatawan, pemerintah, agen perjalanan, dan lain-lain (Widjaja dkk., 2016).

Menurut Nam \& Pardo dalam Buhalis \& Amaranggana (2014) kata smart dalam bahasa pemasaran, berpusat pada perspektif pengguna, yang membuatnya lebih userfriendly daripada cerdas semata. Sementara itu smart tourism sendiri pada dasarnya diadopsi dari konsep smart city yang sudah berkembang sebelumnya (Hidayah, 2018).

Konsep smart city biasanya dikaitkan dengan ekosistem teknologi yang disinergikan dengan komponen sosial untuk meningkatkan kualitas kehidupan warga dan untuk meningkatkan efisiensi pelayanan kota (Egger, 2012 dalam Buhalis \& Amaranggana, 2014). Sebuah kota bisa dikategorikan sebagai smart city, ketika ekonomi tumbuh secara berkelanjutan dan kualitas kehidupan yang tinggi, dimana tercapai dengan investasi pada sumber daya manusia, tingkat partisipasi pemerintah yang merata, dan inftrastruktur yang mendukung penyebarluasan informasi yang tepat di seluruh kota (Caragliu dkk. Dalam Buhalis \& Amaranggana, 2014).

\section{Smart Tourism Destination}

Menurut Buhalis \& Amaranggana, (2014), menerapkan konsep smartness ke dalam destinasi pariwisata membutuhkan para pemangku kepentingan yang saling terkait secara dinamis melalui platform teknologi, dimana informasi yang berkaitan dengan kegiatan pariwisata dapat saling bertukar secara seketika. Platform terpadu ini memiliki banyak touch point yang dapat diakses melalui berbagai perangkat end usesrs yang akan mendukung penciptaan dan fasilitasi pengalaman pariwisata secara realtime dan dapat meningkatkan efektivitas seluruh pengelolaan sumber daya pariwisata, baik pada tingkat mikro maupun tingka makro. Selain itu, Smart Tourism Destinations sebenarnyamemanfaatkan: (1) Lingkungan teknologi (contoh: Internet of Thing, sensor); (2) Kecepatan respon pada tingkat makro dan mikro (contoh: intellegent services, d1l); (3) End-user devices in multiple touch-points (smarphone); (4) Kekompakan para stakeholder dalam menggunakan platform dinamis seperti sistem syaraf.

Tujuan utama smart tourism adalah manfaatkan sistem untuk meningkatkan pengalaman wisata dan meningkatkan efektivitas pengelolaan sumber daya untuk memaksimalkan daya saing dan kepuasan konsumen sekaligus menunjukkan kesinambungan dalam jangka waktu yang panjang (Buhalis \& Amaranggana, 2014).

Smart tourism destinations pada prinsipnya adalah untuk meningkatkan pengalaman pengunjung, menyediakan platform (model) cerdas untuk menyatukan dan mendistribusikan informasi di dalam destinasi, memfasilitasi pengalokasian sumberdaya yang lebih efisien, mengintegrasikan pemasok kepariwisataan pada tingkat makro dan mikro, agar keuntungan yang didapat oleh masyarakat lokal dapat dipastikan (Rong, 2012).

\section{Homestay}

Definisi homestay adalah Fasilitas atau wadah pelayanan menginap atau untuk istirahat bagi wisatawan di daerah wisata dan menekankan suatu 'anti urban' dengan memanfaatkan potensi alami untuk kegiatan rekreasi.Berdasarkan masa penggunaannya, homestay dapat ditempati kapan saja dengan waktu yang tidak terbatas sesuai dengan keinginan. Selain dapat disewakan homestay 
dapat dimiliki oleh perusahaan, dan juga dapat dibeli sebagai sebuah investasi. Jadi homestay dalam penggunaannya dapat digunakan sepanjang tahun.Berdasarkan kegiatan utamanya fasilitas homestay pada tempat wisata dapat berbeda-beda, karena disesuaikan dengan potensi lingkungan setempat, missalnya homestay di daerah pegunungan akan menyediakan fasilitas yang menunjang kegiatan wisata pegunungan, homestay di daerah situs budaya akan menyediakan faslitas yang menunjang kegiatan wisata budaya dan homestay yang berada di daerah pantai akan menyediakan fasilitas yang menunjang kegiatan wisata pantai (Lawson dan Bouy, 1977). Menurut Amirruding (2009) dalam Jamaludin dkk. (2012) program homestay adalah bentuk alternatif akomodasi yang melibatkan kunjungan wisatawan dengan keluarga tertentu dimana mereka dapat berinteraksi dan mengalami kehidupan sehari-hari, serta mengalami budaya asli tuan rumah.

Dalam konsep homestay yang dikemukakan oleh Lawson \& Bovy serta Jamaludin dkk. di atas, terdapat kesenjangan antara konsep dan kenyataan yang terlihat di KEK Tanjung Lesung. Dalam observasi awal yang dilakukan oleh peneliti, konsep homestay yang ada di sana sebagian besar lebih kepada konsep hotel sederhana yang terpisah antara tuan rumah dengan tamu yang menginap, karana terlihat seperti penyewaan kamar yang terpisah antara tamu dan tuan rumahnya, sehingga faktor kedekatan interaksi untuk mempelajari kehidupan dan budaya tuan rumah sehari-hari tidak terjadi.

\section{METODE}

Penelitian ini menggunakan disain penelitian kualitatif dengan pendekatan fenomenografi yang berusaha memahami sudut pandang, pemikiran, pengalaman para stakeholder mengenai kesiapan homestay sebagai salah satu sarana dalam mendukung konsep smart tourism di KEK Tanjung Lesung.

Disain penelitian dilakukan dalam lima langkah sebagaimana yang telah dikemukakan oleh Denzin dan Lincoln (1998), yaitu, 1) menempatkan bidang penelitian dengan menggunakan pendekatan kualitatif; 2) pemilihan paradigma teoritis yakni eksploratif untuk menggali lebih dalam tentang kesiapan homestay sebagai salah satu sarana pariwisata dalam mendukung konsep smart tourism di KEK Tanjung Lesung; 3) menghubungkan paradigma penelitian yang dipilih dengan dunia empiris melalui metodologi; 4) pemilihan metode pengumpulan data; dan 5) pemilihan metode analisis data.

Pengumpulan data yang pertama dilakukan dengan wawancara secara mendalam kepada informan kunci yaitu: 1) Asisten Deputi Tata Kelola Destinasi dan Pemberdayaan Masyarakat Kemenpar; 2) Ketua tim percapatan homestay Kemenpar; 3) Kepala Dinas Pariwisata Provinsi Banten; 4) Administratur KEK Tanjung Lesung; 5) Pengelola Indonesia Tourism Exchange (ITX); 6) Ketua Asosiasi Homestay Kabupaten Pandeglang; 7) Pemilik Homestay di Kabupaten Pandeglang. Hasil wawancara mendalam ini selanjutnya diposisikan sebagai data primer dari penelitian ini.

Selanjutnya observasi dilakukan untuk melihat bagaimana kondisi aktual homestay yang ada, serta untuk menverifikasi berbagai informasi yang diperoleh dari hasil wawancara dengan berbagai informan terkait dengan homestay berbasis desa wisata. Hasil observasi tersebut digunakan untuk mengkonfirmasi atau triangulasi terhadap hasil wawancara mendalam yang telah dilakukan.

Studi dokumen juga dilakukan untuk mengkonfirmasi (trianggulasi) hasil dari wawancara dan observasi yang telah dilakukan. Dokumen yang diteliti diantaranya yaitu Undang-undang No. 10 Tahun 2009 Tentang Kepariwisataan; 2) Peraturan Menteri Pariwisata Nomor 18 Tahun 2016; 3) RENSTRA Kementerian Pariwisata; 4) Dokumen yang terkait dengan Program Homestay berbasis Desa Wisata; 5) Paparan Ketua Tim Percepatan Pengembangan Homestay; dan 6) dokumen 
lainnnya baik cetak maupun elektronik yang berkaitan dengan homestay dan digitalisasi.

\section{HASIL DAN PEMBAHASAN}

\section{Program Homestay dalam Kerangka Konsep Smart Tourism di KEK Tanjung Lesung}

Asisten Deputi Tata Kelola Destinasi dan Pemberdayaan Masyarakat Kemenpar menyatakan bahwa pada dasarnya pencanangan program homestay desa wisata adalah untuk menggerakan ekonomi pedesaan dengan meningkatkan occupancy wisatawan pada destinasi di daerah, yang akan berdampak pada kebutuhan akomodasi yang pengadaannya mudah, murah, cepat yakni homestay sesuai dengan keunikan daerah sebagai identitas bangsa. Sebagai gambaran, bahwa pada tahun 2014, pertumbuhan wisatawan mencapai $10,3 \%$, sedangkan pertumbuhan akomodasi hanya mencapai $8 \%$.

Selain itu, ketertarikan pengunjung terhadap home sharing mengalami kenaikan $10 \%$ (2016) menjadi 15\% (2010) di kota-kota besar dunia dan dari $2 \%$ (2016) menjadi $5 \%$ (2020) di kota-kota besar di Asia Tenggara (The Fourth Industrial Revolution: The Impact on Real Estate in Southeast Asia.Jones Lang LaSalle, 2016).

Dalam menjalankan program homestay, kementerian pariwisata telah membentuk tim percepatan yang bertugas untuk mempercepat program homestay terlaksana. Petunjuk pelaksanaan telah disusun oleh tim percepatan yang intinya kementerian tidak melakukan pengembangan homestay secara fisik, tetapi lebih kepada mempersiapkan jejaring dalam hal pendanaan, mekanisme pembangunan, dan pendampingan dari sisi arsitektur.

Menurut tim percepatan homestay program ini belum memiliki petunjuk pelaksanaan (juklak) yang detil dan terdokumentasi, tetapi baru sebatas melalui pengenalan dan proyek percontohan pada 10 destinasi prioritas dan 10 destinasi branding, serta baru menggodok dan merevisi juklak program homestay yang berbasis desa wisata.

Pemprov Banten juga memandang program ini belum memiliki juklak yang resmi dari Kemenpar, tetapi baru sebatas pedoman homestay dari standar ASEAN. Oleh karena itu Pemprov dan Pemda belum bisa mengoperasionalkan juklak tersebut pada tataran yang lebih teknis.

Hal senada diungkapkan oleh administratur KEK Tanjung Lesung, bahwa belum melihat ada juklak dan juknis (petunjuk teknia) yang jelas jadi hanya baru sebatas pelatihanpelatihan awareness saja belum sampai ke tingkatan juklak. Contohnya seperti sertifikasi, perijinan untuk kelas pondok wisata, atau homestay belum ada. Mungkin karena itu indikator juklak dan jukinsnya belum tersusun jadi mungkin klasifikasi atau pengelompokan itu belum bisa kita lakukan.

Sama halnya dengan pandangan otoritas KEK Tanjung Lesung bahwa program homestay berbasis desa wisata ini belum memiliki Juklak, Juknis atau SOP yang jelas, dan menurutnya indikator dalam penyusunan juklak dan juknis ini belum tersusun, sehingga di kawasan belum bisa mengimplementasikan program tersebut secara terpadu.

Dari hal tersebut di atas maka dapat diambil kesimpulan bahwa program homestay desa wisata dalam kerangka konsep smart tourism di Tanjung Lesung Kabupaten Pandeglang Banten pada dasarnya dicanangkan untuk menggerakan ekonomi dan kesejahteraan masyarakat, tetapi belum memiliki juklak dan juknis yang resmi.

\section{Implementasi Program Homestay dalam Kerangka Konsep Smart Tourism di KEK Tanjung Lesung}

Asisten Deputi Tata Kelola Destinasi dan Pemberdayaan Masyarakat Kemenpar mengemukakan bahwa implementasi program-program homestay dari kementerian pariwisata tersebut sudah berhasil untuk menjebatani dan menginisiasi salah satunya adalah bekerjasama dengan Bank Rakyai Indonesia (BRI) untuk meminjamkan dana 
dalam membangun dan merenovasi homestay. Sementara itu pinjaman tersebut diarahkan untuk dikelola oleh BUMDES (Badan Usaha Milik Desa). Jadi kementerian Pariwisata pada dasarnya tidak memberikan bantuan pinjaman langsung, tetapi lebih kepada menjembatani seperti memfasilitasi. Kementerian Pariwisata juga sedang melakukan pendekatan untuk pemanfaatan dana yang ada di Kementerian Pekerjaan Umum dan Perumahan Rakyat (PUPR) yang merupakan dana stimulan sebesar Rp 15.000.000 untuk merenovasi homestayhomestay yang sudah ada di daerah-daerah. Kementerian pariwisata juga telah merumuskan empat program homestay yaitu, pertama adalah program pengembangan homestay secara fisik (bangun baru, konversi, renovasi), kedua adalah program data base homestay, ketiga adalah program peningkatan kapasitas masyarakat dan keempat program pemasarannya.

Tim percepatan homestay kemenpar menyatakan bahwa sejauh ini terdapat empat skema terkait pembangungan homestay secara fisik. Skema pertama adalah konversi yaitu mengalihfungsikan rumah-rumah yang besar dan memiliki kelebihan kamar menjadi homestay. Skema Kedua adalah renovasi yaitu memfasilitasi pencairan dana terhadap rumah yang belum layak selanjutnya direnovasi menjadi homestay yang layak jual. Skema ketiga adalah revitalisasi yaitu rumah adat yang tidak didiami oleh pemiliknya selanjutnya diperbaiki dan dijual sebagai akomodasi untuk pengunjung. Skema keempat adalah bangun baru yaitu membangun homestay yang baru dengan arsitektur Nusantara tetapi formatnya atau istilah arsiteknya adalah adaptive reuse. Di lapangan sejauh ini ke-empat skema tersebut masih sebatas pengenalan (awareness) dan penjajagan sinergisitas antar pemangku kepentingan yang ada. Adapun pemangku kepentingan yang terlibat sejauh ini diantaranya adalah Kementerian PUPR, Kemendes, Bekraf, Kemensos, Pemprov, Pemda, Pengusaha Cat Propan dan lainnya yang sedang dijajaki. Dalam hal pengenalan, Kemepar telah melakukan sayembara homestay desa wisata bekerjasama dengan Bekraf dan Cat Propan untuk mendapatkan ciri arsitektur homestay di Indonesia. Program ini telah ada pemenangnya dan arsitektur terpilih telah dibukukan oleh Kemenpar.

Sementara itu, menurut Pemprov Banten, pengimplementasian program homestay berbasis desa wisata sejauh ini sudah melakukan kerjasama dengan Dinas Perkim, bekerjasama dengan Kementerian PUPR terkait program 100 homestay, berkoordinasi dengan perbankan dalam hal pendanaan, dan bekerjasama dengan Pemdes dalam penggunaan anggaran desa untuk pembangunan homestay minimal lima homestay di setiap desa wisata.

Lebih lanjut, Otoritas KEK Tanjung Lesung memandang bahwa program homestay berbasis desa wisata sejauh ini di lapangan baru pada tahap diseminasi pengetahuan (awareness) terhadap para pemangku kepentingan. Adapun diseminasi ini lebih kepada pengembangan konsep homestay, mekanisme pembiayaan, dan prosedurprosedur lainnya. Dalam tahap diseminasi konsep, ini dilakukan dengan mengadakan sayembara disain homestaydi 10 destinasi prioritas Kemenpar. Otoritas KEK Tanjung Lesung juga merasa sejauh ini perkembangan homestay berjalan dengan mekanisme pasar, yaitu karena adanya permintaan dan penawaran secara spontan. Hal tersebut terlihat dengan mulai menjamurnya homestay-homestay di sekitar Buffer Zone yang kalau dari sisi konsep bukan benarbenar homestay tetapi lebih ke pondok wisata. Yang sekarang terjadi adalah mekanisme pembagian pangsa pasar, ada permintaan hunian dan masyarakat menyikapinya dengan menyediakan homestay, namun kenyataannya konsep homestay nya sedikit melenceng karena lebih kepada pondok wisata. Ketua asosiasi homestay Tanjung Lesung menilai bahwa capaian program homestay yang berbasis desa wisata, sejauh ini baru sebatas memberi kesadaran (awareness) kepada masyarakat dan pemilik homestay, 
serta penyiapan SDM dalam menyambut program tersebut. Sejauh ini asosiasi homestay melihat bahwa masyarakat dan pemilik homestay sudah melihat peluang dengan digulirkannya program ini, ditambah dengan adanya KEK Tanjung Lesung, sehingga mulai terlihat banyak yang membuka homestay walaupun dengan seadanya, karena belum ada standar dan tatacara pengelolaannya.

Dari penjelasan tersebut maka implementasi program homestay berbasis desa wisata dalam kerangka konsep smart tourism di KEK Tanjung Lesung dilakukan secara bertahap, melalui suatu skema pembangunan homestay yaitu: konversi, renovasi, revitalisasi, dan bangun baru, yang implementasinya dilakukan melalui sinergitas dengan kementerian lain dan melibatkan berbagai stakeholder.

Pemahaman Para Pemangku Kepentingan dalam Menerapkan Smart Tourism di KEK Tanjung Lesung

Asisten Deputi Tata Kelola Destinasi dan Pemberdayaan Masyarakat Kemenpar mengatakan bahwa desa wisata yang ada belum dikembangkan secara utuh ke arah smart destination, hal tersebut dikarenakan oleh belum siapnya produk yang ada untuk dipasarkan secara smart. Oleh karena itu, kementerian pariwisata saat ini lebih fokus terhadap pembangunan 10 destinasi wisata unggulan dan tiga program utama (homestay, digital tourism dan konektivitas). jadi menurut kementerian pariwisata nantinya yang akan menjadi cikal bakal smart destination adalah penggunaan konsep digital tourism di destinasi. Menurut kementerian pariwisata, desa wisata yang sudah berjalan ke arah digital tourism adalah Nglanggeran dan Tembi di Jogja, desa wisata Kemiren di banyuwangi, dan Dieng Kulon. Untuk Kemiren di banyuwangi, kementerian pariwisata sudah menetapkannya menjadi desa wisata percontohan yang menggunakan digital tourism. Sementara desa wisata yang lain masih dalam tahap peninjauan. Kementarian pariwisata memandang KEK Tanjung Lesung belum cukup baik dalam hal pengemasan daya tarik wisata, aksesibilitas, dan sarana prasarananya, sehingga KEK Tanjung Lesung belum dijadikan kawasan prioritas pemasaran.

Sementara itu, ketua tim percepatan homestay mengatakan bahwa Kementerian Pariwisata dalam pengembangannya pada dasarnya sudah mengarah kepada smart toruism. Ketika homestay dibina otomatis nanti SDM dan desanya ikut dibina artinya ketika potensi sudah meningkat peluang mereka untuk bisa mengelola atau menerima tamu harus ditingkatkan lagi karena peluang itu bisa naik kalau digital tidak digital kan gak nyampe nih karena lokasi jauh Bagaimana penerbangan bingung apa jadi informasi - informasi seperti itu nanti akan ada di website-website tersebut. Kalau untuk stakeholder sendiri itu nanti akan diintegrasikan melalui media-media digital yang ada misalnya dengan industrinya dengan swasta dengan pemerintah daerah dengan akademi-akademi atau Sekolahsekolah yang ada.

Senada dengan pandangan ketua tim percepatan, orotitas KEK mengatakan bahwa di KEK Tanjung Lesung sendiri secara administratur sudah berbaiskan on-line system dan salah satu fungsi dari administrator itu yaitu layanan perizinan termasuk TDUP (Tanda Daftar Usaha Pariwisata), kemudian mangawasi berjalannya 1500 hektar kawasan, kemudian yang paling penting sebagai supporting smart tourism yaitu mempromosikan pariwisata Pandeglang dan Banten melalui media on-line. Sehingga otoritas KEK harus selalu update mengenai perkembangan yang ada dan itu semua sudah berbasisikan kepada digitalisasi. Semua pengelolaan pariwisata pandeglang dan Banten akan lebih optimal bila sudah terkoneksi dengan administratur.

Lebih rinci, pihak Indonesia Tourism Exchange (ITX) menjelaskan bahwa homestay dan desa wisata sedang digenjot untuk diperbanyak dan dikembangkan. Ditujukan untuk dapat mengakomodir target kunjungan dan peningkatan daya saing pariwisata khususnya dalam bidang TIK. 
Dikarenakan untuk pembangunan hotel membutuhkan waktu yang cukup lama, sedangkan homestay merupakan akomodasi berbasis komunitas/masyarakat dimana secara bangunan itu sudah ada dan hanya perlu pembinaan. Smart tourism adalah platform pariwisata yang terintegrasi dengan TIK. Di era digital seperti sekarang ini, TIK bisa digunakan sebagai penyampaian informasi dan layanan bagi wisatawan secara efektif dan maksimal. Menurut ITX, kemenpar sudah berorientasi pada smart tourism, hal tersebut terlihat dari penggunaan TIK dan digitalisasi yang digunakan untuk penyampaian informasi dan layanan bagi wisatawan secara efektif dan efisien.

Pemilik homestay melihat implementasi program homstay yang dilakukan oleh Pemda saat ini adalah melakukan pelatihanpelatihan dan sosialisasi kepada para pemilik homestay. Pelatihan-pelatihan tersebut diantaranya adalah pelatihan Bahasa Inggris, pelatihan pelayanan, pelatihan membuat kerajinan khas Tanjung lesung, yang dilakukan sebulan sekali. Sudah beberapa homestay yang sudah memiliki website untuk memasarkan homestay-nya, tetapi dari sisi pengelolaannya belum konsisten. Contohnya www.tanjunglesungbeachhomestay.blogspot. $\underline{\text { co }}$ yang sudah tidak dikelola lagi sehingga sudah tidak dapat diakses. Sementara itu, pelatihan mengenai website tersebut hanya sampai bagaimana cara membuat website saja, belum sampli bagaimana carabekerjasama dengan semacam online travel agent (OTA) seperti traveloka, BnB, atau airy rooms, dll.

Dari hal tersebut, memang masih terdapat perbedaan sudut pandang tentang pemahaman stakeholder dalam menerapkan smart tourism di KEK Tanjung Lesung. Namun demikian, implementasi program homestay yang berbasis desa wisata dalam kerangka konsep smart tourism di sana dilakukan melalui penggunaan teknologi informasi dalam kegiatan pariwisata yaitu yang berkaitan dengan pemasaran digital (digital marketing) seperti; online market place, internet marketing; Pokdarwis dan 10 desa wisata percontohan program ITX.

\section{SIMPULAN}

Program homestay desa wisata dalam kerangka konsep smart tourism di KEK Tanjung Lesung pada dasarnya dicanangkan untuk menggerakan ekonomi di daerah sehingga mampu meningkatkan kesejahteraan masyarakat.

Implementasi program homestay yang berbasis desa wisata dalam kerangka konsep smart tourism di KEK Tanjung Lesung dilakukan secara bertahap, melalui suatu skema pembangunan homestay: konversi, renovasi, revitalisasi, dan bangun baru, yang implementasinya dilakukan melalui sinergitas dengan kementerian lain dan melibatkan berbagai stakeholder.

Terdapat perbedaan sudut pandang tentang pemahaman pemangku kepentingan dalam menerapkan smart tourism di KEK Tanjung Lesung. Namun demikian, implementasi program homestay yang berbasis desa wisata dalam kerangka konsep smart tourism di sana dilakukan melalui penggunaan teknologi informasi dalam kegiatan pariwisata yaitu yang berkaitan dengan pemasaran digital (digital marketing) seperti; online market place, internet marketing; Pokdarwis dan 10 desa wisata percontohan program ITX.

Bertitik tolak dari beberapa temuan penelitian, maka beberapa rekomendasi yang bisa dikemukakan untuk stakeholders yang terkait dengan KEK Tanjung Lesung, beserta saran bagi peneliti selanjutnya yaitu:

Penyusunan juklak dan juknis tidak hanya pada tingkat kementerian, tetapi juga pada ditingkat provinsi, kabupaten, kawasan, dan homestay, sehingga terlihat peran dan fungsinya masing-masing, dengan melibatkan seluruh stakeholders yang ada;

Pemerintah menyusun masterplan mengenai pengembangan homestay yang utuh terkait fisik dan nonfisik di Buffer Zone KEK Tanjug Lesung; 
Segera menuntaskan kerjasama dengan kementerian atau lembaga lain yang terkait, dengan menyusun MOU, untuk meminimalisasi benturan peraturan dengan KL yang lain;

Kemenpar, Pemprov, Pemda, dan pihak swasta, juga perguruan tinggi untuk mensosialisasikan smart tourism kepada para pengelola homestay secara utuh, tidak hanya parsial terkait keberadaan ITX saja;

Pusat dan Pemda bekerjasama untuk mempersiapkan sarana dan prasarana terkait dengan Teknologi Informasi seperti coverage sinyal internet dan lain-lain, karena saat ini, promosi konvensional tidak bisa terlalu diandalkan. Internet lah yang menjadi tulang punggung baru untuk promosi pariwisata daerah. Pengelola harus memiliki website yang representatif dan informatif. Masalahnya, hal ini sampai sekarang masih diabaikan. Banyak website tentang potensi di daerah-daerah yang hanya asal ada dan tidak diperbarui secara rutin. Padahal, website inilah yang menjadi salah satu rujukan utama wisatawan domestik dan mancanegara sebelum memilih destinasi wisata. Selain website, media sosial dan efek word-ofmouth-nya saat ini juga menjadi faktor yang menentukan keberhasilan promosi;

Pemerintah pusat dan Pemda bekerjasama untuk mempersiapkan sarana dan prasarana terkait dengan peningkatan kualitas produk wisata seperti akses jalan, listrik, terminal, dan lain-lain. Karena, tidak ada sektor pariwisata yang sukses tanpa ditunjang infrastruktur memadai. Infrastruktur bisa dibilang merupakan pilar utama untuk mencapai tujuan pariwisata yang berkelanjutan. Artinya, dengan infrastruktur yang semakin baik, maka akan semakin membuat betah wisatawan. Apalagi kalau destinasi wisata memiliki akses yang mudah dijangkau serta menyediakan fasilitas memadai. Ketersediaan berbagai aspek tersebut tidak hanya bertujuan untuk membuat pengunjung nyaman, namun juga akan menambah pun menghargai estetika objek yang diunggulkan.
Pemerintah untuk melakukan pelatihan secara regular kepada pemilik homestay mengenai pelayanan homestay, komputer dan internet;

Mengembangkan daya tarik wisata berbasis laut dan pantai yang terjangkau oleh tamu homestay;

Pemahaman mayoritas masyarakat di desa wisata tentang homestay masih beragam bahkan keliru, maka Pemerintah dan pihak perguruan tinggi kapariwisataan, dan dinas terkait harus melakukan sosialisasi bentuk homestay yang benar, yang sesuai dengan konsep dan peraturan perundangan mengenai homestay sehingga wisatawan mendapatkan pengalaman dan suasana baru setelah menginap di homestay;

Pemerintah menertibkan homestay-homestay yang ada, yang tidak sesuai dengan konsep homestay dengan memberikan insentif atau bantuan pemugaran; dan

Pemerintah pusat, Pemda, dan pihak swasta, juga perguruan tinggi harus bekerjasama untuk membuat aplikasi mobile official kota. Hal ini penting karena dalam mempromosikan pariwisata di daerah, maka pemerintah daerah harus memiliki aplikasi mobile berbasis smartphone. Salah satu contohnya adalah mCity. Keberadaan aplikasi mobile akan memudahkan wisatawan dalam memperoleh informasi dan menjelajahi suatu daerah. Selain itu, aplikasi mobile juga bisa berfungsi untuk membangun city branding. Exposure semacam ini yang sama-sama diharapkan oleh wisatawan, pengelola, maupun investor.

Peneliti selanjutnya disarankan untuk melakukan studi lanjutan di lokasi yang sama namun dengan pendekatan metodologi yang bersifat verifikatif terhadap hasil penelitain ini. Alangkah lebih baik jika dilakukan penelitian tentang topik yang sama dengan pendekatan metodologi yang sama, namun di objek yang berbeda, dimana konsep smart tourism sudah berjalan cukup lama dan berkesinambungan dengan baik. Sehingga dengan dilakukannya penelitian yang terfokus pada topik yang sama dan dilakukan 
dalam waktu yang cukup lama akan diperoleh suatu hasil penelitian yang komprehensif.

\section{REFERENSI}

Anindita, M., Affia P. S., Ghivari A., Ghema G., Pratami T.S., Sherin M.N.I, Ratu S., Yegar A.C.W. (2017). Kebutuhan Pengunjung Terhadap Aktivitas Wisata di Kawasan Tanjung Lesung, Field Project Study, Sekolah Tinggi Pariwisata Bandung.

Buhalis, D., \& Amaranggana, A. (2014). Smart Tourism Destinations. Dublin: IFITT

Denzin, N. K., \& Lincoln, Y. S. (1998). Collecting and Interpreting Qualitative Material. Thousand Oaks, CA: Sage

Gretzel, U., Sigala, M., Xiang, Z., \& Koo, C. (2015). Smart Tourism: Foundations and Developments, Electronic Markets, (25), 179-188

Harrison, C., Eckman, B., Hamilton, R., Hartswick, P., Kalagnanam, J., Paraszczak, J., et al. (2010). Foundations for Smarter Cities. IBM Journal of Research and Development, (54), 1-16

Hidayah, N. (2019). Pemasaran Destinasi Pariwisata, Bandung: Alfabeta

Hidayah, N. (2018). Sekilas Mengenai Smart Destinations, Artikel Tersedia Dalam: https://pemasaranpariwisata.com/2018/ $\underline{01 / 11 / \text { sekilas-mengenai-smart- }}$ destinations/, diakses pada 28 Desember 2019

Höjer, M., \& Wangel, J. (2015). Smart Sustainable Cities: Definition and Challenges dalam L. M. Hilty \& B. Aebischer (Eds.), ICT Innovations For Sustainability, Advances In Intelligent Systems And Computing, 333-349.

\section{New York: Springer}

Jamaludin, M., Norain, O. \& Abdul, R.A. (2012). Community Based HomestayProgramme: A Personal Experience. Procedia - Social and Behavioral Sciences (42), 451-459

Lawson, F \& Boud-Bovy M. (1977).

Tourism and Recreation Development, A Handbook of Physical Planning, London: Architectural Press

Peraturan Menteri Pariwisata Nomor 18 Tahun 2016 Tentang Pendaftaran Usaha Pariwisata

Rencana Strategis Kementerian Pariwisata (Renstra) Periode 2015-2019

Rong, A. (2012). China Economic Net, Tersedia Dalam: http://en.ce.cn/Insight/201204/12/t2012 0412_23235803.shtml

Undang-undang No. 10 Tahun 2009 Tentang Kepariwisataan

Wang, H., Jin, T., \& Zhou, B. (2012). Smart Tourism. Beijing: Tsinghua University Press

Werthner, H., Koo, C., Gretzel, U., \& Lamfus, C. (2015). Special Issue on Smart Tourism Systems: Convergence of Information Technologies, Business Models, and Experiences. Computers in Human Behavior, (50), 556-557.

Widjaja, A.E., Hery, R.E.T. (2016). Meningkatkan Potensi Pariwisata Danau Toba Melalui Konsep Smart Tourism: Aplikasi Dan Tantangannya, Makalah Tersedia Dalam: https://retariganforbranding.files.wordp ress.com/2016/12/makalah-andree-ewidjaja-hery-riswan-e-tariganmeningkatkan-potensi-pariwisatadanau-toba-melalui-konsep-smarttourism.pdf 
www.tanjunglesungbeachhomestay.blogspot. $\underline{\text { co }}$

Yahya, A. (2017). Top 3 Program Prioritas Kementerian Pariwisata. Tersedia Dalam:

https://article.wn.com/view/2017/04/07 /Menpar_Arief_Titipkan_Top_3_Progr am_Prioritas_Kemenpar_2017/, diakses pada tanggal 07/08/17

Yahya, A. (2017). Homestay Desa Wisata.

Tersedia Dalam:

https://bisnis.tempo.co/read/news/2017 /05/18/090876586/homestay-desa wisata-portofolio-baru-kembangkanpariwisata,diakses pada tanggal 07/08/17,

\section{BIODATA PENULIS}

Nurdin Hidayah, merupakan Senior Lecturer Jurusan Kepariwisataan Sekolah Tinggi Pariwisata Bandung, dengan fokus bidang kajian tourism marketing dan business strategy.

Id Scholar:

https://scholar.google.co.id/citations?hl=id\& user=lCcv1nMAAAAJ

Herlan Suherlan, merupakan Associate Professor Jurusan Kepariwisataan Sekolah Tinggi Pariwisata Bandung, dengan fokus bidang kajian education administration dan tourism administration

Id Scholar:

https://scholar.google.co.id/citations?hl=id\& $\underline{\text { user}=d c U W d l k A A A A J}$ 